\title{
Short Tandem Repeat
}

National Cancer Institute

\section{Source}

National Cancer Institute. Short Tandem Repeat. NCI Thesaurus. Code C13441.

Area of repetitive DNA within the genome consisting of multiple, end-to-end copies of a short DNA sequence usually comprised of di-, tri-, or tetranucleotide repeat units. 